\title{
BILINGUALISM AND CREATIVITY
}

\section{Szerzők:}

Mihaela Birescu (Ph.D.)

Gál Ferenc University

Szerző e-mail címe:

mihaela.birescu@gmail.com
Lektorok:

Mező Ferenc (Ph.D.)

Eszterházy Károly Katolikus Egyetem

Szabóné Balogh Ágota (Ph.D.)

Gál Ferenc Egyetem

és további két anonim lektor...

\section{Absztrakt}

\section{KÉTNYELVÜSÉG ÉS KREATIVTTÁS}

A játék nagyon hatékony tanulási eszköz a gyerekek számára, és ezt a legtöbb oktatási rendszer elismeri. A játéktevékenységek a következőkhöz kapcsolódnak: felfedezés, szórakozás, szabadság, nyomozás, tájékozódás, tanulás, szociális fejlődés, szorongásokkal való megbirkózás, a világ megértése és az energiafelhasználás. A játék során a gyerekek képességeiket fejlesztik - például nyelveket tanulnak, és ezt négy alapelv szerint teszik: élvezet, módszer, rendszer és türelem. A kétnyelvű gyakorlat javítja a kognitív mechanizmusokat, ami a kreatív potenciál növekedéséhez vezethet. A kétnyelvű és kreatív oktatás ötvözésével a kognitív mechanizmusok segítenék az egyéni kreatív teljesítményt, és egy szinergikus kétnyelvű kreatív oktatási modellt hoznának létre.

Kulcsszavak: kétnyelvűség, kreativitás, oktatás, nyelvek, játék, tulajdonságok, gyerekek

Diszciplína: pszichológia, pedagógia

\section{Abstract}

Play is a very effective learning tool for children, and most of the educational systems admit this. Play activities are linked to: exploration, fun, freedom, investigation, enquiry, learning, social development, coping with anxieties, making sense of the world and using up energy. Through play, children develop abilities - for example they learn languages, and they do so, by four principles: enjoyment, method, system, and patience. Bilingual practice improves cognitive mechanisms, which may lead to increased creative potential. By combining bilingual and creative education, the cognitive mechanisms 
would help the individual creative performance and would create a synergetic bilingual creative model of education.

Keywords: bilingualism, creativity, education, languages, play, attributes, children

Discipline: psychology, pedagogy

Birescu, Mihaela (2021): Bilingualism and Creativity. OxIPO - interdiszciplináris tudományos folyóirat, 2021/4, 31-37. doi: 10.35405/OXIPO.2021.4.31

\section{Bilingualism: learning or playing?}

Is developing language proficiency a problem of talent, flexibility, opportunity, method, or motivation? For children, the question is centered on their essential activity: play. Play is linked to creativity; and the creative act fosters the development of cognitive and affective processes, through the thinking actions that take place during role play, for example. If playing facilitates thinking, then would it be all right to extend this to the assumption that playing facilitates creativity? Play is a very effective learning tool for children, and most of the educational systems admit this. Peter Blatchford (1998) in his study of school playtimes, states that schools in $\mathrm{UK}$ tend to shorten the playing time in favor of teaching time in classrooms, and this leads to behavior problems. The adults keep complaining about the lack of social skills in today's children; but we are the ones stealing their playtime - a time offering opportunities to meet and develop relations with each other.

\section{What is play and why is it important?} Play activities are linked to: exploration, fun, freedom, investigation, enquiry, learning, social development, coping with anxieties, making sense of the world and using up energy.

Beginning with the European Enlightenment and Romantic eras and the writing of people such as Rousseau (1712-78), Pestalozzi (1747-1827) and Froebel (1782-1852), writers have identified different functions of play, and, play has, therefore, been valued for a range of different reasons:

- it is a natural part of the innocence of childhood;

- it burns some energy;

- it helps understanding the social reality;

- it develops the cognition;

- it helps exteriorizing feelings and emotions;

- it builds communication skills;

- it challenges children to learn, to be creative, to make mistakes. 


\section{Theories of play}

Play helps children successfully immerse into the social world. Montessori placed emphasis on children's self-initiated learning. Piaget's theories about learning emphasized the need for children to explore and experiment for themselves. Vygotsky emphasized the social and cultural aspects of play. He argued that during play children were able to think in more complex ways than in their everyday lives, and could make up rules, use symbols and create narratives. The ways in which play can support children's developing communication skills has been explored and documented by a number of researchers who draw attention to the way children in primary school playgrounds use language for a variety of purposes, including organizing and structuring their games, imaginary play, and reinforcing social hierarchies (Hyder, 2005).

It is very interesting that Froebel's theories from 1887 still apply in today`s kindergartens:

- free play encourages discoveries and finds purpose in everyday life;

- each child develop at their own pace because they learn differently;

- the teachers are not the keepers of knowledge, but they lead and guide the children to try, to make mistakes, to understand;

- teachers should make the classroom a proper environment for the children`s development;
- let them move - play, sing, dance, manipulate objects - all help a better understanding process.

\section{Education: the four principles of developing language proficiency}

It is really crucial to find ENJOYMENT in the learning process. And, as seen above, play ensures this feature. But it is not enough. For achieving fluency in another language, 3 more principles need to be applied.

First of all, a METHOD is required. If I have to memorize a telephone number, I 11 probably do it without any problem. But I'll also forget it in several hours. Also, a student will memorize a list of words for a test during the following day. But the short term memory will work against their benefit: the student will forget the words in a few days. They will have to put those words into situations and repeat those contexts for the next days. As teachers, fortunately we are familiar with lots of such contexts, that we call methods.

The third principle to follow is to create a SYSTEM, which includes perfect timing, joggling with moments and opportunities to use that language. So, the important thing is to create a plan in the learning. It is the teacher's job to make the planning. But making the language part of the students everyday life is not only a job, but a calling, an endeavor, a plan involving lots of cultural factors during an extended period in the day. 
PATIENCE is an equally important factor. Preschoolers do not feel the pressure of speaking the second language fluently, but, as they grow up and get into a superior educational system, they tend to get discouraged and embrace the feeling of shame for incorrect assertions.

Our today`s kindergarten children will be the active workforce in 2061. We have no idea about how the future will look like in 5 years... How can we educate them for their future? The children are extraordinary: they are creative and very talented. Yes, they all have talents, but we are nullifying it without regrets. Talent has the same importance as literacy, and we should treat these two with the same importance. A child is not afraid of being wrong, thus a child is not afraid to try. If you are not prepared to be wrong, you will not come up with anything original. On the road to adulthood, most of the kids had lost this capacity. In our society, we got used to stigmatize mistakes. The worse place to make mistakes is the national educational systems almost everywhere. The result is that we, as teachers, educate people out of their creative capacities. Our problem is we do not grow into creativity, but we grow out of it; in fact, we are educated out of it. Most educational systems work basically on this hierarchy: mathematics and languages, then humanities are at the bottom of the arts. Unfortunately, the academic abilities still dominate the concept of intelligence, as the universities designed the system on their image.

\section{Creative bilinguals}

Studies have shown that bilingual individuals have greater creative performances, because speaking more languages develops the cognitive capacities. And creativity can be found in enhanced cognition. Bilingual practice improves cognitive mechanisms, which may lead to increased creative potential. The past few years showed progress in researching the cognitive development of the bilinguals (Bialystok, 2005). One of the results of these researches is that bilingual development results in redesigning the mind to promote later cognitive advantages. Due to the creative cognition approach, creativity is defined as a product of cognitive functioning. This approach suggests that the creative products are original and useful (Mayer, 1999); then the ideas may facilitate a creative performance. Studies (e.g. Ricciardelli, 1992) showed that language proficiency has an impact on the capacity of creative thinking. Bilinguals also demonstrated:

1. greater innovative capacity and more vivid imagination;

2. greater fluency, flexibility and creative thinking, if an additional language had been added at a younger age (Kharkhurin, 2012);

3. a greater immersion into the cultures of both languages (Simonton, 2008). 


\section{Bilingual education}

\section{and creative education}

In 2008, the Commission of European Communities identified the need for innovation and creativity in education and it stated that multilingualism is one of the main aspects in education. It is a long time, though, since the academic community had underlined the importance of introducing creativity into the educational systems. Its value of a crucial factor for the future of the human race was also pointed out. In spite of all these, schools show little interest in fostering creativity; on the contrary, creativity seems to be suppressed in the classrooms, as teachers ' methods provide little opportunities for the development of the students `creative capacities: conformity comes before innovativeness; habitual behavior towards the system comes before its critical evaluation. The academic system rather demonstrates a fear to make radical changes in substituting a standard education with a creative one. A combination of bilingual education and language learning with implementing creativity might be a solution for reviving the educational system.

By combining bilingual and creative education, the cognitive mechanisms would help the individual creative performance and would create a synergetic bilingual creative model of education. Regarding the relationship between bilingualism and creativity, Marsh and Hill (2009) found that multilingualism increases the capacity for original and abstract thinking and improves flexibility in thinking and reasoning. The interpersonal communication skills are also developing and stimulate the capacity to learn even more languages.

\section{Attributes}

\section{of the creative bilingual education}

Kharkhurin (2012) found five attributes of the bilingual creative education, necessary to the teachers who want to develop creative thinking.

\section{Personal attributes:}

- sense of purpose,

- motivation,

- stimulating and rewarding curiosity, exploration,

- tolerance for ambiguity,

- developing self-esteem, self evaluation,

- self-improvement and self-comparison (competition is not to be eliminated, but it becomes secondary in importance),

- developing esthetic sense.

\section{Cognitive attributes:}

- building general curricular knowledge in two languages, for the chance of rehearsal,

- acquisition of domain-specific language,

- developing convergent thinking - analyzing and synthesizing information (making the students see connections, similarities, overlaps, and logical implications), 
- simultaneously processing several pieces of information,

- employing new strategies and conceptual plans,

- not problem solving, but problem finding,

- self-evaluation and self-management in language learning and creative behavior,

\section{Administrative attributes:}

- innovative leadership in schools,

- customized learning environment (communitarian, economical, sociocultural),

- the teachers', students' and parents' attitudes, beliefs, assumptions and expectations are equally important,

- establishing bonds between clusters of teachers and students (and efficiently grouping the students),

- ongoing professional staff development,

- multiplying the opportunities for the students to engage in the learning process,

- articulation of school modules, utilizing bilingual creative education.

\section{Environmental attributes:}

- developing a sense of what the students hope to accomplish,

- acceptance of the behavior of the students and of their creative urges,

- opportunities for practice the acquired abilities outside the school,

- adaptive mobility acceptance,
- involving parents in the school activities,

- involving social services, to meet the students' needs,

- smart and coordinated use of the existing resources,

\section{Curricular attributes:}

- use of the teaching strategies of the curriculum in two languages,

- adaptation to a diversity of languages and cultures,

- use of student-directed strategies for enhancing language development and creativity; adopting an open teaching and learning approach (Urban, 1995),

- a balanced curriculum, using different levels of skill for the students, developing all the domains equally,

- a systematic students` assessment, based not on judgment, but on performance monitoring, in order to implement different teaching strategies,

- teachers are encouraged to organize class creatively, for a student friendly environment,

- encouraging teachers to have greater, more independent decision-making power.

\section{Instead of conclusion}

\section{(as it is still an open debate)}

It seems we need to rethink everything about the educational system, at least in this part of Europe. Maybe we need to be $\mathrm{ECO}$ and $\mathrm{BIO}$ with ourselves, not just 
with the environment. We are undermining ourselves; maybe we need to redefine the values of the human potential. The education system we are part of is going to pollute our minds - it is doing to us exactly what we are doing to the environment - it digs for some commodity, but this won't serve us in the future.

Which are the future fundamental principles of educating our children? Celebrate the human imagination; celebrate our creative capacities - our true treasure; celebrate our children as they are our hope. Let's educate the whole that they are - for the future (a future that is theirs, that we might not even live to see)!

\section{References}

Amabile, T. M. (1983). The social psychology of creativity. New York: Springer-Verlag.

Bialystok, E. (2005). Consequences of bilingualism for cognitive development. In J. F. Kroll \& A. de Groot (ed.), Handbook of bilingualism: Psycholinguistic approaches (pp. 417-432). New York: Oxford University Press.

Blatchford, P. (2008). The state of play in schools. In ACAMH, v.3, iss. 2 (pp. 58-67). Journal of School Health.

Froebel, F. (1887). The education of man. (W. N. Hailmann, Trans.). D

Appleton \& Company. Web: https://doi.org/10.1037/12739-000.
Goleman, D. (1996) Emotional Intelligence, London, Bloomsbury.

Hyder, T. (2005) War, Conflict and Play, London: Routledge.

Kharkhurin, A. V. (2012). Multilingualism and creativity. Bristol, UK: Multilingual Matters.

Marsh, D. \& Hill, R. (2009). Study on the contribution of multilingualism to creativity. Final report. Brussels: European Commission.

Mayer, R. E. (1999). Fifty years of creativity research. In R. J. Sternberg (ed.), Handbook of creativity (pp. 449460). New York: Cambridge University Press.

Ricciardelli, L. A. (1992). Creativity and bilingualism. Journal of Creative Behavior, 26 (4), (pp. 242-254).

Runco, M. A. (2004). Creativity. Annual Review of Psychology, 55, (pp.657-687).

Simonton, D. K. (2008). Bilingualism and creativity. In J. Altarriba \& R. R. Heredia (ed.), An Introduction to bilingualism: Principles and processes (pp. 147-166). Mahwah, NJ: Lawrence Erlbaum Associates.

Urban, K. K. (1995). Openness: A magic formula for an adequate development and promotion of giftedness and talents?! Gifted and Talented Intrnational, 10, pp.15-19. 